\title{
INTERNATIONAL SOCIAL SCIENCE JOURNAL
}

\section{Edited by Ali Kazancigil}

\section{" Each issue of the International} Social Science Journal takes up a theme of broad social significance and presents research findings and syntheses from all parts of the world. Anyone wishing to obtain an interdisciplinary and global perspective on current world problems, from the micro to the macro levels, ought surely to read the ISSJ'.
Recent articles include:

Modelling the interrelation between macro-society and the family

Laszlo Cseh-Szombathy

Bio-technological developments and the law Tor Sverne

Demographic family changes in contemporary Japan

\section{Fred W Riggs, University of Hawaii Kiyomi Morioka}

\section{ORDER FORM}

Subscription Rates, Volume 43, 1991

Individuals $\mathbf{2 2 . 0 0}$ (UK), $\mathbf{2 4 . 0 0}$ (Europe), $\$ 46.80$ (N America), $\mathbf{2 6 . 0 0}$ (Rest of World)

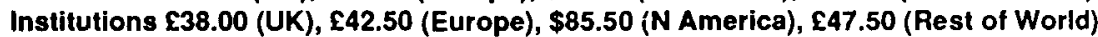
Published quarterly

$\square \quad$ Please enter my subscription/send me a sample copy

I enclose a cheque/money order made payable to Basil Blackwell

Please charge my Access/American Express/Diners Club/

Mastercard/Nisa account number

For payments via the National Girobank, the Basil Blackwell account number is 2366053

Name

Address

Postcode

Signature

Date

Payment must accompany orders

Please return this form to: Journals Marketing Manager, Basil Blackwell,

108 Cowley Road, Oxford OX41JF, England. Registered No. 180277. Or to: Journals Marketing Manager, Basil Blackwell. Three Cambridge Center, Cambridge, MA 02142, USA 
To Craft Democracies An Essay on

Democratic Transitions GIUSEPPE DI PALMA

"Giuseppe Di Palma's book could not be more timely, given the snowballing events that are gaining momentum in Eastern and Western Europe.... It represents a truly fresh look at the red-hot issues of transitions to democracy."

-Joseph LaPalombara, Yale University 260 pages, $\$ 35.00$ cloth $\$ 11.95$ paper

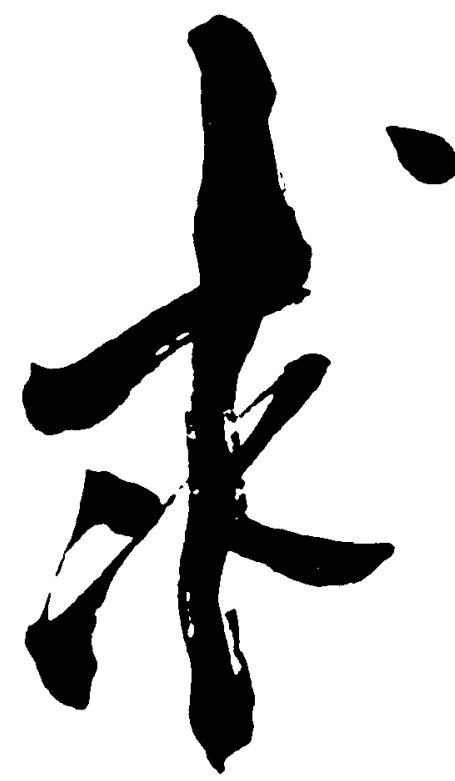

Brushes with Power Modern Politics and the Chinese Art of Calligraphy RICHARD CURT KRAUS

"In Kraus's hands, the study of calligraphy becomes a metaphor fora much wider topicthe persistence of traditionalism in modern China .... By focusing on a small aspect of that traditionalism - but an aspect with deep metaphorical resonance -the author helps us to gain a more focused understanding of Chinese cultural life." -Richard Madsen, author of Morality and Power in a Chinese Village 224 pages, illustrated, $\$ 24.95$ cloth
The Establishment of Communist Rule in Poland, 1943-1948 KRISTINA KIRSTEN

Translated and annotated by John Micgiel and Michael H. Bernhard Foreword by Jan T. Gross First published underground in Poland in 1984, this inside look at Communist subjugation is now available to the English reader. Nowhere has the takeover of any East-Central European country been so searchingly documented by a writer who waslivingat the time under the imposed Communist regime. Societies and Cut lure in East-Central Europe, 8 548 pages, $\$ 49.95$ cloth

National Ideology Under Socialism

Identity and Cultural Politics in Ceausescu's Romania KATHERINE VERDERY

"Raises questions and suggests answers that are central to all 'Soviet Bloc' countries."

- Andrew Lass, Mount Holyoke College Societies and Cultures in East Central Europe, 7 422 pages, $\$ 39.95$ cloth

Nested Games

Rational Choice in Comparative Politics GEORGE TSERELIS

New in paperback- "This book establishes Tsebelis as one of the foremost scholars in applying rational choice analysis to the field of comparative politics. . . The notion of nested games greatly expands the domain of formal analysis while also rendering game theory more capable of reflecting political reality."-David Cameron, Yale University 288 pages, \$29.95 cloth, \$13.95 paper

At bookstores or order toll-free 1-800-822-6657. Visa/MasterCard. UNIVERSITY OF CALIFORNIA PRESS

Berkeley Los Angeles New York Oxford 


\section{BULLETIN OF PEACE PROPOSALS}

\section{RECENT CONTENTS}

Vertical and Horizontal Proliferation in the Middle East/Persian Gulf Sverre Lodgaard

Neutralization: The Key to an Arab-Israeli Peace Efraim Karsh

Back to the Worid: Recent Changes in Vietnamese Domestic and Foreign Policy Duong Quoc Thanh

The Triumph of Democracy: Toward a Century of Hope Daisaku lkeda

The Greening of Europe Jacques Grinevald

The United Nations Disarmament Training for Diplomats: Hopes for the Future Sola Ogunbanwo

The Two Nordens: The North and the South, or the East and the West? Ola Tunander

Ecoregions, State Sovereignty and Conflict

\section{Bruce Byers}

Answered Prayers: Fukuyama. Liberalism and the End-of-History Debate

Torbjørn L. Knutsen

Making and Breaking Enemy Images William Eckhardt

Revolutionary Social Defence Brian Martin

Soviet Defence Decision-making: a Postscript Carl G. Jacobsen

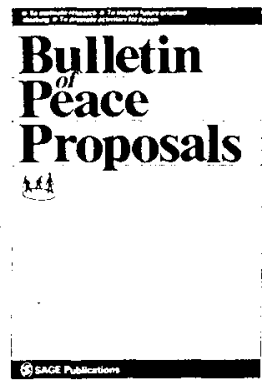

Edited by Magne Barth

The Bulletin of Peace Proposals has successfully bridged the gap between academic peace research and peace action. It's standards have always been high, and coverage of the most urgent problems of the contemporary world has always been up to date. Many of the BPP's articles become highlights in an ongoing debate. One does not want to miss it.' Dr Dieter Senghaas

Published quarterly in March, June September and December

\section{Make sure that you subscribe now!}

\section{Use the order form below and save. $20 \%$}

$20 \%$ Discount Order Form

Send this order form to

\section{Sage Publications}

6 Bonhill Street, London EC2A 4PU, UK Tel: $071-3740645$

Or why not fax us your order on

071-374 8741?

\section{US Orders to:}

PO Box 5096. Newbury Park, CA 91359. USA

$\exists$ Yes! I want to subscribe to Bulletin of

Peace Proposals at a $20 \%$ Discount

$J$ individual Rate at $£ 20\left(£ 25^{*}\right) / \$ 32\left(\$ 40^{*}\right)$

- Institutional Rate at $\Sigma 46\left(\Sigma 58^{*}\right) / \$ 74\left(\$ 93^{*}\right)$

-Usual 1991 rate

Name

Address

\section{THREE WAYS TO PAY!}

u CHEQUE!... I enclose a cheque (made payable to Sage Publications)

[ GIRO!... I have today paid by International Giro to A/C No 5480353

Date

$\exists$ CREDIT CARD!... Please charge my credit card

$\checkmark$ Mastercard $\square$ Access $\square$ Visa

\lrcorner Barclaycard $\lrcorner$ American Express

$\checkmark$ Diner's Club I Eurocard

Card Numter

Expiry Date

Signature

Date 


\section{FROM GORBACHEV TO THE SHAH}

\section{Gorbachev's Struggle for Economic Reform}

Updated and Expanded Edition

By ANDERS ASLUND. From a review of the original edition - "There is no better, more politically sophisticated account of Mr.

Gorbachev's economic program and the obstacles that stand in its way."-New York Times Book Review. \$44.95 cloth, \$14.95 paper

\section{The Fall of the Athenian Empire}

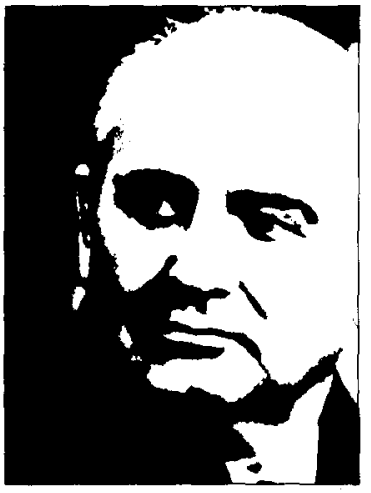

By DONALD KAGAN. New in Paper! "No less than, say, the Napoleonic invasion of Russia or the Japanese strike at Pearl Harbor, the Athenian expedition against Sparta's allies in Sicily seems to incarnate the malignant genius and ironies of war itself. ... Kagan's patient scrutiny of the diplomatic and domestic background of this fatal thrust is masterly."-George Steiner, New Yorker. $\$ 13.95$

\section{The Nationalization of the Masses}

Political Symbolism and Mass Movements in Cermany from the Napoleonic Wars through the Third Reich

By GEORCE L. MOSSE. New in Paper! "[Mosse] has made an important and unique contribution to the literature on nationalism and totalitarianism."

-American Historical Review. \$12.95

\section{Toxic Politics}

Responding to Chemical Disasters

By MICHAEL R. REICH. A comparative study at the politics of chemical disasters, with a focus on the victims and their struggles for redress, this book takes a searching look at a major environmental and social problem of our time. $\$ 45.00$ cloth, $\$ 15.95$ paper

\section{U.S. Foreign Policy and the Shah}

Building a Client State in Iran

By MARK GASIOROWSKI. "Gasiorowski has seen a crucial fact that American policy-makers have ignored: to reinforce an authoritarian state in the name of protecting freedom undermines the freedom of that state's own citizens. Anyone who cares about American foreign policy in the Third World will gain from reading Gasiorowski's analysis."-Charles Tilly, New School for Social Research. $\$ 35.00$ 


\section{JOURNAL OF PEACE RESEARCH}

\section{RECENT CONTENTS}

Focus On:

The Greening of Peace Research

Dennis Clark Pirages

\section{Articles:}

Improving Communications Links Between

Moscow and Washington

Desmond Ball

Sex Differences in Nuclear War Attitudes

Patricia A. Gwartney-Gibbs \& Denise H.

Lach

Economic Incentives and International

Cooperation: Technology Transfer to the

People's Republic of China

William J. Long

'Economic Warfare'and'Strategic Goods': A

Conceptual Framework for Analyzing

\section{COCOM}

Tor Egil Forland

Human Rights and the Allocation of US

Military Assistance

Steven C. Poe

Tension Between the Strong, and the

Strategies of the Weak

Hans Mouritzen

Review Essay:

Feminist Perspectives on Peace Education Annika Takala

\section{Journal \\ Peace Research \\ $2 \times 1$}

S SAGE Publection

Edited by Nils Petter Gleditsch

'It has consistently kept its readers around the world abreast of major theoretical developments, new formulations of conflict and peace stategies and processes, and documentation of research findings. It has given a struggling interdisciplinary field coherence and kept us all to a high standard of work.'

Elise Boulding

Published quarterly in February, May, August and November

\section{Make sure that you subscribe now!}

\section{Use the order form below and save $20 \%$}

\section{$20 \%$ Discount Order Form}

Send this order form to:

\section{Sage Publications}

6 Bonhill Street, London EC2A 4PU, UK Tel: 071-3740645

Or why not fax us your order on

071-374 8741?

\section{US Orders to:}

PO Box 5096, Newbury Park, CA 91359, USA

a Yes! I want to subscribe to Journal of Peace Research at a $20 \%$ Discount

$\square$ Individual Rate at $\mathbf{E 2 0}\left(£ 25^{*}\right) / \$ 32\left(\$ 40^{*}\right)$

$\checkmark$ Institutional Rate at $£ 46\left(\sum 58^{*}\right) / \$ 74\left(\$ 93^{*}\right)$

"Usual 1991 rate

Name

Address

\section{THREE WAYS TO PAY!}

- CHEQUE!... I enclose a cheque (made payable to Sage Publications)

] GIRO!... I have today paid by International Giro to A/c No 5480353

Date

口 CREDIT CARD!... Please charge

my credit card

- Mastercard D Access $\square$ Visa

$\square$ Barclaycard $\square$ American Express

$\square$ Diner's Club $\square$ Eurocard

Card Number

Expiry Date

Signature

Date 


\section{New in Politics}

\section{Governing from the Center}

Politics and Policy-Making

in the Netherlands

\section{Ken Gladdish}

Combining an examination of the evolution of the Dutch polity with a survey of current politics, Ken Gladdish includes in his analysis the most recent general election held in September 1989.

"Very solid, comprehensive, sensibly organized, written in a clear and straightforward style. . . Gladdish clearly knows Dutch politics very well indeed, and he writes with justified authority."-Arend Lijphart

191 pages $\$ 30.00$ cloth

\section{Paul Leroy-Beaulieu and Established Liberalism in France}

\section{Dan Warshaw}

As economist, journalist, company director, and politician, Leroy-Beaulieu represents more than any of his contemporaries the French upper bourgeoisie and the established school of liberalism. In this detailed analysis, Warshaw explores Leroy-Beaulieu's imperialist thought and brings to the surface new insights into the origins and nature of liberal imperialism.

267 pages $\$ 30.00$ cloth

\section{and \\ History}

Trygve Lie and the Cold War

The UN Secretary-General Pursues Peace, 1946-1953

James Barros

"Barros approaches the man and his times in a thoroughly balanced and scholarly manner in this most impressive book."-Foreign Affairs

Drawing from rare sources, the author examines the role of the newly formed UN, under Lie's direction, in moderating post-World War II conflicts in such settings as Spain, Greece, Israel, Iran, and Berlin.

444 pages $\$ 37.00$ cloth

\section{The Great Reforms}

Autocracy, Bureaucracy, and the Politics of Change in Imperial Russia W. Bruce Lincoln

Lincoln examines the origins and the significance of the Great Reforms and evaluates the results of the reforms in the context of Russia's experience between the Crimean War and the Revolution of 1905. His analysis of the history of reform offers startling insights into the nature of glasnost and perestroika today.

296 pages $\$ 29.00$ cloth

$\$ 12.00$ paper

\section{Northern Illinois University Press}

DeKalb, Illinois 60115-2854

(815) 753-1075 


\section{The Journal of International Affairs EAST CENTRAL EUROPE: AFTER THE REVOLUTIONS}

How did the 1989 democratic revolutions in East Central Europe change the region's geopolitical balance? What are the prospects that the newly elected regimes will live up to their promises of economic prosperity and political freedom and equality? A diverse group of experts explores and analyzes these and other vital questions, offering their insights, explanations and predictions for the coming years.

\begin{tabular}{|c|c|c|}
\hline \multicolumn{3}{|l|}{ Contributors include: } \\
\hline$+\quad$ Ellen Comisso & 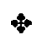 & Imre Oravecz \\
\hline Bronislaw Geremek & $\div$ & George Schoepflin \\
\hline Dan Hamilton & $\leftrightarrow$ & Herman Schwartz \\
\hline Kenneth Jowitt & 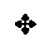 & Gregory Treverton \\
\hline * Deborah Milenkovitch & 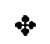 & Stanislaw Wellisz \\
\hline
\end{tabular}

Don't Miss This Timely Issue of the Journal. Subscribe now!

Annual Subscription:

$\square$ Individual (\$14.00)

$\square$ Institution (\$28.00)
Single Issues:

$\square$ Individual (\$7.00)

$\square$ Institution (\$14.00)

Name

Institution

Address

City/State/Zip

Send order to JA, Box 4, International Affairs Building, Columbia University, New York, NY 10027. Foreign postage: \$4/year. No foreign postage necessary for U.S., Canada or Mexico. 


\section{PETER LANG}

\section{GLASNOST" \\ Deception, Desperation, Dialectlcs}

\section{by Montecue J. Lowry}

GLASNOST' constitutes and presents an interpretation of events in the Soviet Union and Eastern Europe which differs from that propagated by Mikhail S. Gorbachev.

"The cold war may be over, but you'd better read this superb analysis of GLASNOST' before you decide. As we live through the great changes taking place in this decade, here is a scholarly and urgent warning that should be read and must be heeded." General Glenn K. Otis, United States Army, Retired "GLASNOST' should be read by everyone who is interested in a factual and welldocumented analysis of Mikhail Gorbachev and the continuing threat of Soviet Communism." Major General Henry Mohr, United States Army, Retired 1991 ISBN 0-8204-1522-7 287 pp. 2 fig. hardcover $\$ 46.95$

COUNT STEPHEN TISZA, PRIME

MINISTER OF HUNGARY

Letters (1914-1916)

Translated by Carvel de Bussy

«[This book] adds a great deal to the information available concerning [Count Stephen Tisza], as well as to the era (WWI). It should become a frequently read resource volume for scholars, historians and political scientists in particular, dealing with that period in Central and Eastern Europe. The book fills a void not covered by others ..." Craig W. Nickish, Idaho State University

1991238 pp. 14 ill.

ISBN 0-8204-1412-3

hardcover $\$ 46.95$

POLITICAL CHANGE AND SOCIAL DEVELOPMENT: THE CASE OF THE SOVIET UNION

by Alexander Shtromas

Contents:

- The Problem of Political Opposition in the USSR

- The Soviet Regime and the Soviet People: A Historical Survey

- Present Consensus and Dissent

- Political Change : Prospects, Ways, Consequences

2nd ed. $1990173 \mathrm{pp}$.

ISBN 3-631-42187-0 papercover $\$ 34.80$

\section{AGAINST DEMOCRACY AND EQUALITY \\ The European New Right \\ by Tomislav Sunic}

Prefaced by Paul Gottfried, the book examines the legacy of arevolutionary conservatism» in Europe and its chief protagonists among the European New Right. Unlike previous works, the book focuses on the cultural contribution of conservatism to the political process in Europe.

\section{$1990208 \mathrm{pp}$.}

ISBN 0-8204-1294-5 hardcover \$39.95

\section{POLITICAL SOCIALIZATION OF THE YOUNG IN EAST AND WEST \\ Ed. by Bernhard Claussen \& \\ Horst Mueller}

The articles in this reader examine the political socialization and political education in Turkey, India, East and West Germany, Great Britain, USA, Hungary, Poland and in the Netherlands. They present different theoretical approaches to political socialization, and examine the East-West relations in political education.

$1990336 \mathrm{pp} .2 \mathrm{ill}$. and num. charts ISBN 3-631-43116-3 papercover $\$ 68.80$

\section{New York • Bern • Frankfurt/M. • Berlin • Wien • Paris}




\title{
Center of $\mathrm{P}$ nternational $\circlearrowright$ tudies
}

\author{
PRINCETON UNIVERSITY
}

\section{POSITIVE PRESCRIPTIONS FOR THE NEAR FUTURE \\ A World Order Perspective \\ By Richard Falk}

This paper summarizes the most recent work of the World Order Models Project, a transnational scholarly collaboration on the theme of drastic global reform that was initiated in the mid-1960s. The focus is on "rooted utopianism," an extension of political horizons beyond conventional ideas of feasibility and on the special opportunities/challenges posed by the end of the cold war.

World Order Studies Program

Occasional Paper Number 20

Order from the

Center of International. Studies

Bendheim Hall, Princeton, N.J. 08544

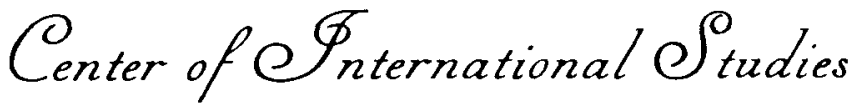

PRINCETON UNIVERSITY

\author{
TOWARD NEW ORDERS IN THE MIDDLE EAST \\ The Role of U.S. Policy \\ John Waterbury, Editor
}

After the sixth major war in the Middle East since 1948 and the first in which U.S. and Arab forces engaged in combat, it is important that the United States seize the opportunity to bring about conditions that will lessen the possibility of future wars. A group of twenty-one prominent scholars of the contemporary Middle East met in May to devise a set of recommendations on U.S. policy toward the region in the near and medium term. This report is a synthesis of their debates and conclusions.

Center of International Studies

Monograph Series

Number 2

Order from the

Center of International Studies

Bendheim Hall, Princeton, N.J. 08544 


\title{
A new comprehensive reader for the classroom and library \\ SOVIET FOREIGN POLICY Classic and Contemporary Issues
}

\author{
Edited by Frederic J. Fleron, Jr., Erik P. Hoffmann, \\ and Robbin Laird
}

A major new collection of studies on Soviet foreign policy, designed to help government, business, legal, and media professionals, as well as students, assess the international aims, activities, and accomplishments of the USSR. Wellknown analysts explore significant issues in Soviet foreign relations from the era of the Bolshevik Revolution and the Civil War to the unfinished, still unfolding era of reform.

Among the contributors are Helmut Sonnenfeldt, William G. Hyland, Raymond L. Garthoff, William Zimmerman, Vernon V. Aspaturian, Adam B. Ulam, George F. Kennan, Allen Lynch, Susan L. Clark, F. Stephen Larrabee, Donald S. Zagoria, and Robbin F. Laird.

$$
\begin{gathered}
\text { Soviet Foreign Policy } \\
\text { Classic and Contemporary Issues } \\
\text { 1991. } x v+858 \text { pages. 0-202-24170-X. Cloth } \$ 69.95 \\
0-202-24171-8 \text {. Paper } \$ 34.95
\end{gathered}
$$

To meet the individual needs and interests of the reader, the essays in Soviet Foreign Policy are also available in two separate volumes: Classic Issues in Soviet Foreign Policy: From Lenin to Brezhnev and Contemporary Issues in Soviet Foreign Policy: From Brezhnev to Gorbachev.

$$
\begin{aligned}
& \text { Classic Issues in Soviet Foreign Policy } \\
& \text { From Lenin to Brezhnev } \\
& \text { 1991. xv + 350 pages. 0-202-24172-6. Paper } \$ 22.95
\end{aligned}
$$

Contemporary Issues in Soviet Foreign Policy

From Brezhnev to Gorbachev

1991. xv + 524 pages. 0-202-24173-4. Paper $\$ 24.95$

\section{Aldine de Gruyter}

(a division of Walter de Gruyter, Inc.)

200 Saw Mill River Road

Hawthorne, NY 10532 Tel: (914) 747-0110 


\begin{tabular}{|c|c|}
\hline \multirow{2}{*}{ 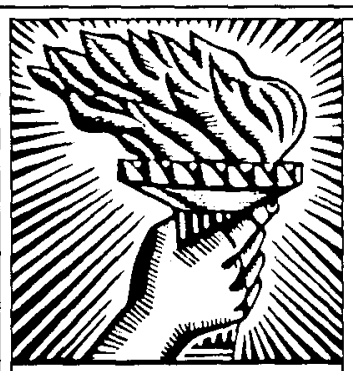 } & Now at Johns Hop \\
\hline & Marc F. Plattner and Larry Diamond, Editors \\
\hline $\begin{array}{l}\text { EDITORIAL BOARD } \\
\text { Chinua Achebe } \\
\text { Shaul Bakhash } \\
\text { Naomi Chazan } \\
\text { Charles H. Fairbanks, Jr. } \\
\text { Harry Harding } \\
\text { Samuel P. Huntington } \\
\text { Atul Kohli } \\
\text { Leszek Kolakowski } \\
\text { Leopold Labedz } \\
\text { Liang Heng } \\
\text { Juan J. Linz } \\
\text { Seymour Martin Lipset } \\
\text { Joshua Muravchik } \\
\text { Ergun Özbudun } \\
\text { Octavio Paz } \\
\text { Susan Kaufman Purcell } \\
\text { Peter Reddaway } \\
\text { Alfred Stepan } \\
\text { Arturo Valenzuela } \\
\text { Ernest J. Wilson III }\end{array}$ & $\begin{array}{l}\text { Drawing on the recent profusion of democratic schol- } \\
\text { arship and activism, the Journal of Democracy monitors } \\
\text { and analyzes democratic movements and reports on } \\
\text { newlyestablished democracies around theworld. Lead- } \\
\text { ing political analysts and scholars put current events } \\
\text { into perspective, examining the social, political, and } \\
\text { cultural factors that affect the institutionalization of } \\
\text { democracy. Headline-making activistsgive first-hand } \\
\text { accounts of their struggles and strategies for democ- } \\
\text { racy within their own countries. The Journal also } \\
\text { includes election results, key documents on democ- } \\
\text { racy, topical book reviews, and reports on meetings } \\
\text { and conferences. Insightful analyses and front-line } \\
\text { reporting make this leading international forum of } \\
\text { scholarship a showcase for a variety of competing } \\
\text { democratic viewpoints. } \\
\text { Published quarterly in January, April, July, and } \\
\text { October. }\end{array}$ \\
\hline$=-=-=$ & $-\cdots-\cdots-\cdots-\cdots-\cdots$ \\
\hline $\begin{array}{c}\text { JOURNAL OF } \\
\text { DEMOCRACY }\end{array}$ & $\begin{array}{l}\text { Send orders to: Journals Division, THE JOHNS } \\
\text { HOPKINS UNIVERSITY PRESS, 701 W. 40th } \\
\text { St., Suite 275, Baltimore, MD 21211-2190 }\end{array}$ \\
\hline 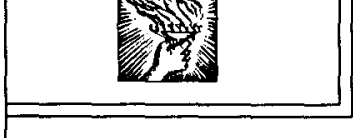 & $\begin{array}{l}\text { For MasterCard and VISA orders, call toll- } \\
\text { free 1-800-537-JHUP or FAX us your order: } \\
301-338-6998 \text {. }\end{array}$ \\
\hline $\begin{array}{l}\text { Yes! Please start my st } \\
\square \text { \$24.00 individuals } \\
\square \text { Check or money } \\
\square \text { Charge my: } \square] \\
\text { Acct.\# }\end{array}$ & $\begin{array}{l}\text { bscription for one year of Journal of Democracy. } \\
\square \$ 45.00 \text { institutions } \\
\text { rder enclosed payable to JHUP. } \\
\text { ISA } \square \text { MasterCard Exp. Date }\end{array}$ \\
\hline Signc & \\
\hline & \\
\hline $\begin{array}{l}\text { City } / \text { State } / Z i p \\
\text { Prepayment requirec } \\
\text { GST. Add } \$ 3.50 \text { post }\end{array}$ & Canada an \\
\hline
\end{tabular}




\section{THE ECONOMIC DIPLOMACY OF THE SUEZ CRISIS \\ by Diane B. Kunz}

"A fascinating contribution to the story of Britain's attempt to maintain its role as an economic world power, of the uses of and limitations on U.S. economic power and, more generally, of the role of economic matters

in modern diplomacy."-Roger Owen approx. 300 pp., $\$ 39.95$

\section{THE BOURGEOIS EPOCH}

Marx and Engels on Britain, France, and Germany by Richard F. Hamilton

"A hard-hitting, well-written, informative and polemical work that will certainly command a respected place in what is now the mainstream specialty of sociological history."--James B. Rule approx. 331 pp., $\$ 37.50$ cloth, $\$ 13.50$ paper

\section{RECENT AWARD WINNERS}

\section{BETWEEN CHURCHILL AND STALIN}

The Soviet Union, Great Britain, and the Origins of the Grand Alliance by Stephen Merritt Miner George Louis Beer Prize, American Historical Association 329 pp.. $\$ 36$

\section{UNITED STATES EXPANSIONISM AND BRITISH NORTH AMERICA, I775-I87I}

by Reginald $C$. Stuart

Albert B. Corey Prize, American Historical Association 390 pp. $\$ 39.95$

available at bookstores or from

THE UNIVERSITY OF NORTH CAROLINA PRESS

Post Office Box 2288 - Chapel Hill, NC 27515-2288 


\section{Subscribe to the joumal that is making history.}

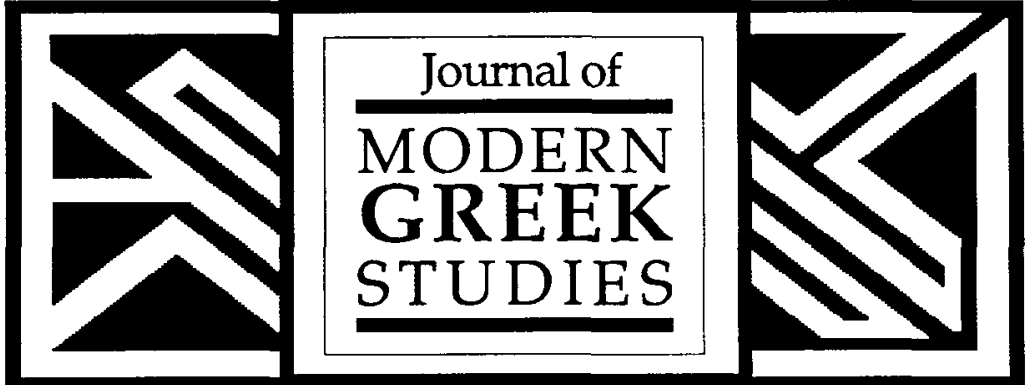

Official Publication of the Modern Greek Studies Association Peter Bien, Editor

Adamantia Pollis' important essay, "The Missing of Cyprus: A Distinctive Case" will be read into the Congressional Record by Senator Joseph Biden. The Senator has also invited the author to testify on the problems of Cyprus before a congressional committee. Subscribe today and read this article and many others in Volume 9, Number 1.

Contents include: "Enlightened" Concepts in the "Dark": Power and Freedom, Politics and Society/Constantine Tsoucalas - Cyprus TwentyFive Years Later: An American Diplomat Looks Back/Charles W. McCaskill - The Missing of Cyprus: A Distinctive Case/Adamantia Pollis - The Social Organization of Exile: The Everyday Life of Political Exiles in the Cyclades in the 1930s / Margaret E. Kenna - Greek Romany as a Written Language: A Text in Greek Translation/ Gordon M. Messing • The Third Wedding: Woman as the Vortex of Feeling/ Nicholas Kostis - Pontic Performance: Minority Theatre vs. Greek Ideology/ Patricia Fann • plus book reviews.

Journal of Modern Greek Studies is published in May and October.

- - - - - - - - - - - - - - - - - -

Send orders to: The Johns Hopkins University Press, Journals Division, 701 W. 40th St., Suite 275, Baltimore, MD 21211-2190. FAX: 301-338-6998.

Plcase enter my one-ycar subscription to Journal of Modern Greek Studies.

$\square \$ 19.00$ individuals $\square \$ 40.00$ institutions

$\square$ Check/moneyorderenclosed payable:Johns Hopkins University Press.

$\square$ Charge my: $\square$ VISA $\square$ MasterCard Exp.Date

Acct.\#

Signature

\% Or call toll-frec 1-800-537-JHUP for VISA or MasterCard orders.

Name

Address

City/State/Zip

Prepayment required. Foreign postage: $\$ 3.50$, Canada and Mexico; $\$ 4.00$ outside N. America. Payment must be drawn on aU.S. bank or made by international money order. MD residents add $5 \%$ sales tax. For orders shipped to Canada add 7\% GST (GST \# 124004946).

EA1

\section{Joumal of MODER G REEK ST UDIES}




\section{Previous Award Recipients}

Aaron L. Frieberg

The Weary Titan

Princeton University Press

Stephen M. Walt

The Origins of Alliances

Cornell University Press

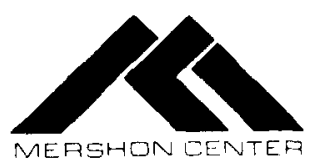

\section{Announcing the 1992 \\ Edgar S. Furniss Jr. \\ National Security \\ Book Award}

Andrew F. Krepinevich, Jr

The Johns Hopkins University

Press. 1986

Bruce G. Blair

Strategic Command and

Control

Brookings Institution

Barry R. Posen

The Sources of Military

Doctrine

Cornell University Press

John J. Mearsheimer

Conventional Deterrence

Cornell University Press

A $\$ 1,000$ cash prize will be awarded to the author of a book published in 1991 that makes an exceptional contribution to the study of national security or the role of the military in society. The award, which commemorates the first director of the Mershon Center, is restricted to the author's first published book. Nominations by authors, publishers, or third parties must be made by February 28, 1992.

For more information, contact:

Don Lair

Mershon Center

The Ohio State University 199 West 10th Avenue Columbus, $\mathrm{OH} 43201-2399$ 614-292-1681 


\section{ASIAN PERSPECTIVE}

\section{A Biannual Journal of Regional \& International Affairs}

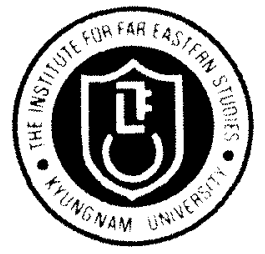

published by

The Institute for Far Eastern Studies Kyungnam University

Publisher: Jae Kyu Park

Editor-in-Chief: Man Woo Lee

\section{Titles of Recent and Up-Coming Articles:}

The Evolution of U.S.-China Security Relations and Its Implications for the Korean Peninsula

Military Capabilities of South and North Korea: A Comparative Study Japan's Governing Triad: Models of Development and Policymaking Imported Asian Labor in the USSR

Radical, Reformers, and the Chinese Tradition

The 1989 Tiananmen Square Incident: Retrospective and Prospective Considerations

Is Indonesia Poised for an Economic Takeoff?

Book Review

Asian Perspective publishes distinguished articles on social sciences in general and particulary world/comparative politics and Asia's regional affairs. Manuscripts should be consistent with the statement on the inside back cover.

Articles for publication should be submitted in duplicate.

\section{Subscription Rates(1992-93):}

* one year US\$22.00 (by surface-mail)

*one year US\$26.00 (by airmail)

"two vears US\$40.00 (by surface-mail)

"two years US\$48.00 (by airmail)

\section{Orders to:}

The Institute for Far Eastern Studies, Kyungnam University 28-42 Samchung-dong,

Chongro-ku, Seoul 110-230, Korea 


\section{Postdoctoral Fellowship for Research in International Security Studies.}

The Mershon Center is seeking applicants lor postdoctoral research in international security aftairs. Possible areas of interest include:

- U.S. delense and foreign policy

- international conflict resolution

- military history

- civit-military relations

Preference will be given to applicants with a solid design for completing a book-length manuscript during the fellowship year. The appointment will be for up to twelve months beginning July 1 , 1992. The stipend will be at approximately $\$ 29,000$ per annum. Only persons holding a doctorate awarded since June 1987 are eligible to apply.

If interested, request an application package from:

Fellowship Coordinator

Mershon Center

The Ohio State University

199 West Tenth Avenue

Columbus, OH 43201-2399

(614) 292-1681

Applications due November 15, 1991

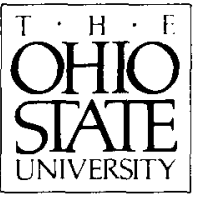




\section{Scandinavian Journal of Development Alternatives Stockholm, Sweden}

This is a journal with an interdisciplinary focus in the social sciences. It is both theoretical and practical nature, and seeks to confront and deal with every aspect of human development, covering all the socio-economic systems of the world. It has interest in such issues as basic social needs, fulfillment of human rights, avoidance of both class and other structural violence the search for disarmament and peace, the maintenance of ecological balance, the removal poverty and unemployment, improvement in North-South relations, and the finding of international framework to deal equitably with trade, industrialization, migration, technology transfer, and general socio-economic disparities of a regional or a global kind.

Articles from past and recent issues include:

Noam Chomsky: Scenes from the Uprising in West Bank and Gaza.

J. David Singer: From Promised Land to Garrison State: The Israeli Search for Security

Richard Falk: Nuclearism and National Interest-the Situation of a Non-Nuclear Ally

Winston Langley: Why Did the U.S. Withdraw from UNESCO?

Francis A. Boyle: Citizen Initiatives Under International Law: The Criminality of Nuclear

Weapons

Hans P. Buvolle: Communal Lands and Armed Conflict in the Atlantic Regions of Nicaragua. Lalitha Althumudali: Conflict in Sri Lanka and Perception of the U.S. Role

Tyronne Fernando: Internationalization of Ethno-Political Issues of Sri Lanka and its Impact on Foreign Relations.

C. Suriyakumaran: The Anatomy of National Identity in Sri Lanka.

A. Aziz: Ethnic Conflict in Sri Lanka: An Analysis.

Kenneth Fernando: Christian Perception and Ethnic Crisis in Sri Lanka.

Ilja A Luciak: Participatory Development in Sandinista Nicaragua: Grass-Roots Movements and Basic Needs

Panos D. Bardis: Ethiopia: Mengistu and Marxism

Joe L.P. Lugalla: Prospects and Problems of Regional Cooperation in Africa: A Case Study of SADCC

Franklin Vivekananda and Rashmi Shrivastava: Prospects and Crisis in Punjab

Stephen Zunes: Participatory Democracy in the Sahara: A Study of Polisario Self-Govemance

Rajni Kothari: Programme on Peace and Global Transformation

Amalendu Guha: Conflict and Cooperation between the United States and the Euro-NATO in the Seventies and Eighties: Economic, Military and Political Dimensions

Georg Sorensen: How Cold is the Second Cold War? An Assessment of the Scope of the 'Grea Contest'

Hibbert R. Roberts: The Reagan Administration and the Middle East: Peace, Palestinians, and Israelis

Donald E. Schulz: The United States, Honduras, and the Crisis in Central America

Send Orders to SJDA, P.Box. 7444. 10391 Stockholm. Sweden. 


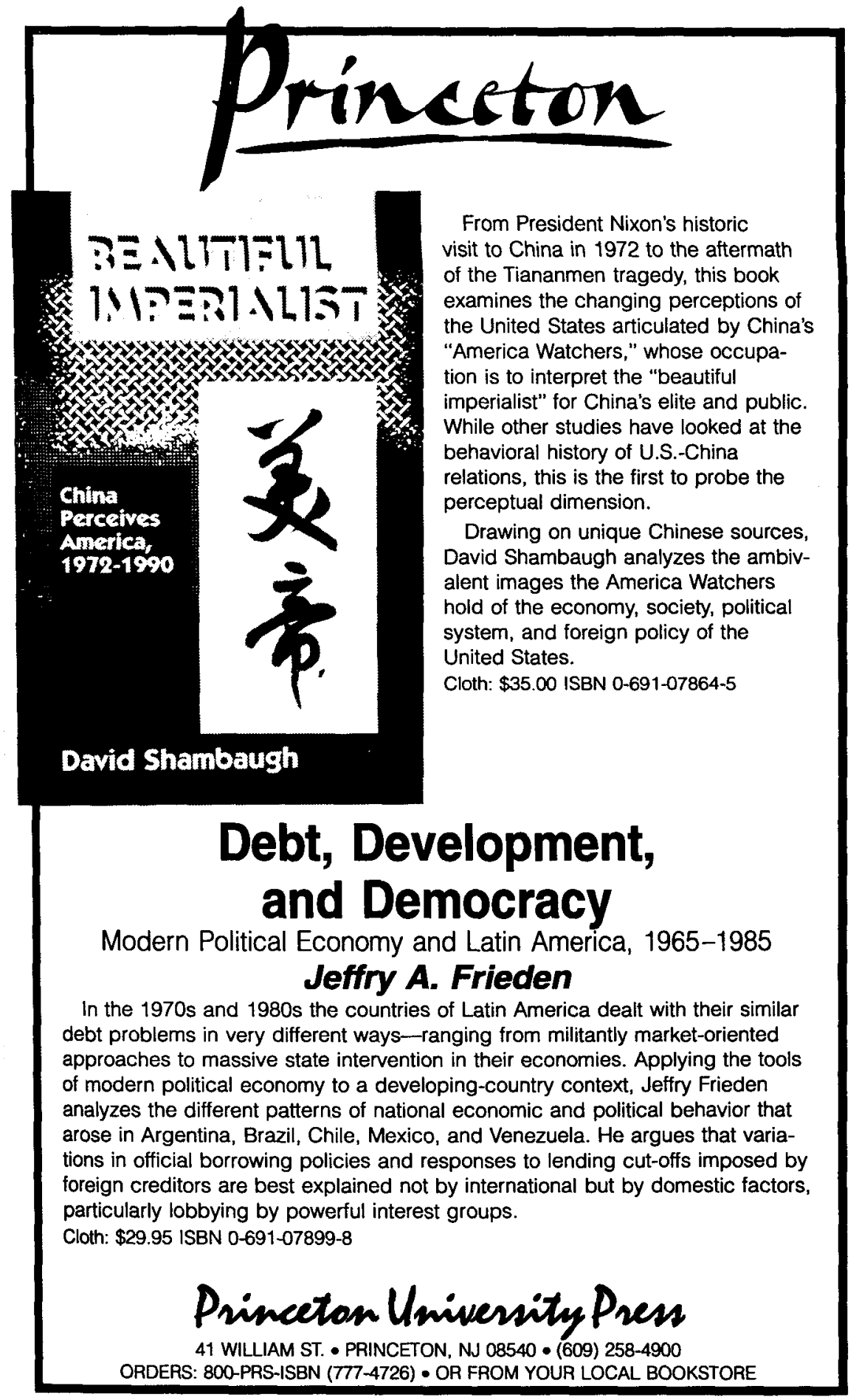




\section{For those who prefer knowledge over opinion}

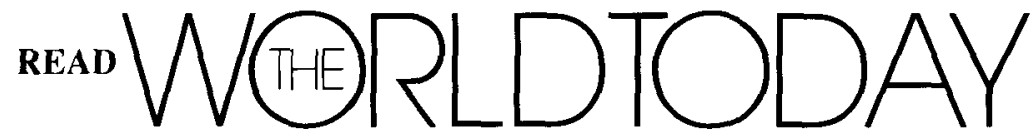

\section{Send for a free sample issue with no obligation to subscribe}

THE WORLD TODAY, established in 1945, is the monthly journal of the Royal Institute of International Affairs, Chatham House, London. It is a unique magazine of international politics. It covers the broad issues alongside the small ones. It covers the politics of countries that are not in the headlines today, but could be there tomorrow. It opens up questions for the scholar and fills in gaps for the general reader. And it takes a balanced point of view. The experts seem to agree.

'THE WORLD TODAY is thoroughly researched and clearly written. It provides valuable background information and its choice of subjects is catholic and intelligent.'

Rupert Pennant-Rea, Editor of The Economist

'THE WORLD TODAY is topical, to the point, a good halfway house between daily and weekly press and academic journals. I read it for useful background and insights.'

Andrew Knight, Chief Executive of The Daily Telegraph

'THE WORLD TODAY taps the best available expertise on international subjects. I recommend it to anyone who wants a greater depth and specialist expertise on a range of topics of current interest.'

SEE FOR YOURSELF:

\section{Read}

THE WORLD TODAY

by filling in the

coupon for

your free

sample issue
The World Today

10 St James's Square

London SWIY 4LE

\section{Please send me a free sample issue.}

Name

Address

Country

Subscription rates:

UK Institutional £27 Individual £22 Student £17

US Institutional $\$ 65$ Individual $\$ 43$ Student \$28

Europe and elsewhere Institutional \$33 Individual \$28 Student \$25

Written by the experts. Read by the experts. 